Geoff Brumfiel, Washington

Proposed changes to an obscure set of export rules could derail US research, say academic and industrial groups, who are now frantically trying to raise the alarm among scientists.

The modified rules would require academic researchers from countries including China and India to obtain a government licence before operating a wide range of lab equipment in the United States. In a 22 April letter to university department chairs, Judy Franz, executive officer of the American Physical Society, warned that the changes constitute a "potential threat to research". And this week, the National Academies are convening a special workshop to inform scientists of the proposed changes.

At issue is a set of rules governing the export of sensitive technologies. Known as the Export Administration Regulations, the rules are meant to limit the transfer of equipment that could advance the military might of 'countries of concern' - a list that includes China, India, Pakistan and Russia. The regulations also require researchers from these countries working with some items of equipment to obtain a licence from the US Department of Commerce.

Traditionally, universities have thought themselves exempt from the regulations. But a March 2004 report from the Department of Commerce's Office of Inspector General, an independent watchdog, argued that the regulations do apply to academic labs. The report also proposed expanding the criteria under which a licence would be required for using controlled equipment, and applying the rules

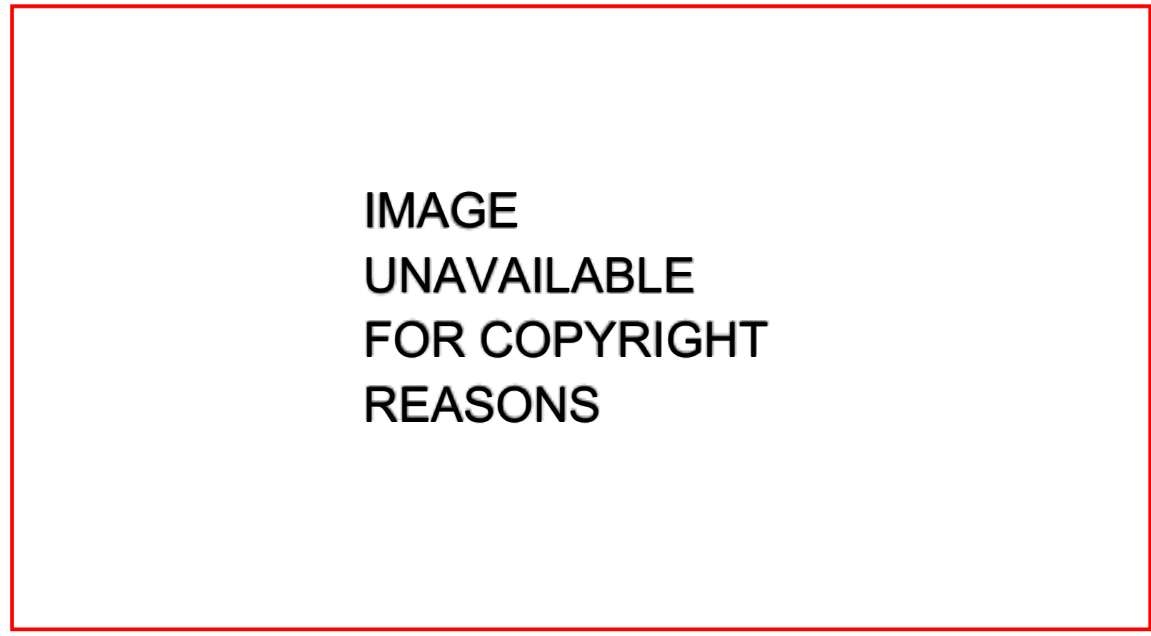

Dye lasers are one type of equipment that nationals from some countries may need a licence to use.

by country of birth rather than country of citizenship (see Nature 431,615;2004).

The 45-page equipment list indudes common lab apparatus such as lasers and sealed glove boxes for handling hazardous material. Getting a licence for each potential user would overwhelm lab supervisors, warns Dan Mote, president of the University of Maryland, who is scheduled to talk at a National Academies workshop. "This really is potentially devastating," he says. "It's quite conceivable that this would just bring work to a halt."

Industry is also concerned, according to Cynthia Johnson, director of government relations for Texas Instruments, a major US semiconductor manufacturer. Although industrial labs alreadyhave to comply with the rules, the proposal to base the regulations on a researcher's country of birth rather than citizenship could alienate fresh talent, she says.

Department of Commerce officials stress that they are still far from making a final decision about how to modify the rules. "What we are doing is seeking input," says Peter Lichtenbaum, assistant secretary for export administration.

That is why it is important for researchers to weigh in with their objections, says Arthur Bienenstock, a physicist and dean of research and graduate policy at Stanford University in California. "What the Department of Commerce needs is an honest assessment of what it would mean if the inspector-general's rules were implemented, ${ }^{n}$ he says. The comment period closes on 27 May.

\title{
Hubble rescue mission gears up despite shuttle setback
}

\section{Tony Reichhardt, Washington}

The space shuttle Discovery will have to wait at least another seven weeks before returning to duty, NASA decided last week. But preparations for an astronaut servicing mission to the Hubble Space Telescope will resume anyway - another sign that new NASA administrator Michael Griffin may reverse his predecessor's decision to abandon the telescope later in the decade.

NASA managers reluctantly revised Discovery's launch date from 22 May for several reasons, but primarily because of concerns about ice debris from the shuttle's giant fuel tank. The $\mathbf{2 0 0 3}$ demise of Columbia, the last shuttle to fly, occurred after foam insulation falling from the tank shortly after launch gouged a hole in the shuttle's wing. NASA engineers consider foam the greatest danger, but a technical review last week concluded that falling ice still poses a small risk. So heaters will probably be installed to prevent ice forming on the tank - a time-consuming job.

The next available launch window for the shuttle - determined by factors ranging from the International Space Station's orbit to lighting conditions for cameras to inspect the vehicle as it leaves the launch pad opens on 13 July and lasts until 31 July.

Meanwhile, engineers at the agency's Goddard Space Flight Center in Maryland will resume planning for the shuttle servicing mission to Hubble that was suspended by former administrator Sean O'Keefe.

Griffin won't decide whether to approve the mission until after the shuttle's return, but said last week that he wanted to keep the option open. Based on new estimates of when Hubble's batteries and gyroscopes will fail, project managers now think that the telescope can be serviced as late as 2010.

Griffin also said that, despite the delay in returning to flight, he considers the $\mathbf{2 0 1 0}$ target for retiring the shuttle "very firm", and that NASA is looking for ways to complete the space station using other launch vehicles. This could mean that the schedule for conducting research on the station will slip.

For now, though, the orbiting laboratory will get what it needs from elsewhere: a Russian Progress vehicle will deliver supplies next month that the shuttle would have carried. And although the station's international partners are disappointed by the delay, said programme manager Bill Gerstenmaier, "they understand the decision". 